\title{
Pro-oxidative effect of peroxynitrite regarding biological systems: a special focus on high-molar-mass hyaluronan degradation
}

\author{
Eva Hrabarova ${ }^{1}$, Ivo Juranek ${ }^{2}$ and Ladislav Soltes ${ }^{2}$ \\ ${ }^{1}$ Department of Carbohydrate Enzymology, Institute of Chemistry, Slovak Academy of Sciences, Bratislava, Slovak \\ Republic \\ 2 Institute of Experimental Pharmacology and Toxicology, Slovak Academy of Sciences, Bratislava, Slovak Republic
}

Dedicated to Professor Radomir Nosál, MD, DSc on the occasion of his 70th birth anniversary

\begin{abstract}
Current understanding on the role of peroxynitrite in etiology and pathogenesis of some human diseases, such as cardio-vascular diseases, stroke, cancer, inflammation, neurodegenerative disorders, diabetes mellitus and diabetic complications has recently led to intensive investigation of peroxynitrite involvement in physiology and pathophysiology.

Mechanism of cytotoxic effects of peroxynitrite involve its reactions with lipids, DNA/RNA, proteins, and polysaccharides, thus triggering cellular responses ranging from subtle changes of cell functioning to severe oxidative damage of the affected macromolecules leading to necrosis or apoptosis. The present work is aimed at providing a brief overview of i) peroxynitrite biosynthesis and reaction pathways in vivo, ii) its synthetic preparation in vitro, and iii) to reveal its potential damaging role in vivo, on actions studied via monitoring in vitro hyaluronan degradation. The complex biochemical behavior of peroxynitrite is determined by a number of variables, such as chemistry of the reaction itself, depending mostly on the involvement of conformational structures of different energy states, concentration of the species involved, content of reactive intermediates and trace transition metal ions, contribution of carbon dioxide, presence of trace organics, and by the reaction kinetics. Recently, in vitro studies of oxidative cleavage of hyaluronan have, in fact, been the subject of growing interest. Here we also describe our experimental set-up for studying peroxynitrite-mediated degradation of hyaluronan, a system, which may be suitable for testing prospective pharmacological substances.
\end{abstract}

Key words: Antioxidants - Hyaluronan degradation $-3-N$-Morpholinosydnonimine - Peroxynitrite - Reactive oxygen and nitrogen species

\begin{abstract}
Abbreviations: ASC, ascorbate; $\mathrm{CO}_{3}{ }^{\circ-}$, trioxocarbonate anion radical; SOD, superoxide dismutase; ECM, extracellular matrix; ecNOS, endothelial-constitutive form of NOS; EDRF, endothelium-derived relaxing factor; EPR, electron paramagnetic resonance; GAGs, glycosaminoglycans; GSH, l-glutathione; GS*, glutathionyl radical; GSNO, S-nitrosoglutathione; ${ }^{\circ} \mathrm{NO}$, nitric oxide radical; ${ }^{\circ} \mathrm{NO}_{2}$, nitrogen dioxide radical; NOS, nitric oxide synthase; ${ }^{1} \mathrm{O}_{2}$, singlet oxygen; ${ }^{\circ} \mathrm{OH}$, hydroxyl radical; $\mathrm{ONOO}^{-}$, peroxynitrite anion; $\mathrm{ONOOH}$, peroxynitrous acid; $\mathrm{O}_{2}{ }^{--}$, superoxide anion radical; RONS, reactive oxygen and nitrogen species; SIN-1,3-Nmorpholinosydnonimine.
\end{abstract}

Correspondence to: Eva Hrabarova, Department of Carbohydrate Enzymology, Institute of Chemistry, Slovak Academy of Sciences, Dubravska cesta 9, Bratislava, Slovak Republic

E-mail: eva.hrabarova@savba.sk 


\section{Introduction}

Under conditions of increased production of superoxide anion radical $\left(\mathrm{O}_{2}{ }^{\bullet-}\right)$ and nitric oxide radical $\left({ }^{\circ} \mathrm{NO}\right)$, these two radicals may react together yielding a more potent prooxidant, peroxynitrite anion $\left(\mathrm{ONOO}^{-}\right)$. These reactive species differ in their half lives and thus their distances they can diffuse from their original sites are different. Half life of $\mathrm{O}_{2}{ }^{--}$anion radical determines its potential distance of diffusion to $0.4 \mu \mathrm{m}$ thus limiting its action to an intracrine one, i.e. within the cells of their origin or in a very close vicinity of them. On the other hand, half life of ${ }^{\bullet} \mathrm{NO}$ radical enables it to diffuse through the tissue up to $100 \mu \mathrm{m}$ thus allowing it to exert a paracrine action on neighboring cells. And, the half life of $\mathrm{ONOO}^{-}$determines its diffusion distance to $\sim 5$ $\mu \mathrm{m}$, so it can act rather locally (Pacher et al. 2007).

Peroxynitrite is capable of nitrating proteins at their tyrosine residues thus producing nitrotyrosine (Radi 2004). The nitration and covalent modification of proteins and DNA by $\mathrm{ONOO}^{-}$is termed nitrative stress, which has been first observed as accumulation of nitrotyrosine residues in atherosclerotic plaques (Beckman et al. 1994a), and also in the placenta (Myatt 2010). Later, it has been found in many other pathologies, particularly those associated with inflammation (Myatt et al. 1996; Lyall et al. 1998).

Indeed, peroxynitrite, one of the most important endogenous oxidizing and nitrating species, is a mediator of cellular and tissue injury in various pathophysiological situations. Biochemical pathways of this metabolite, producing free radicals, are responsible for the oxidative and nitrosative stress in biological systems (Pacher et al. 2003, 2005; PérezDe La Cruz et al. 2005).

Peroxynitrite formation in vivo and its behavior in the organism have been reported (for review, see Murphy et al. 1998; Pacher et al. 2007). ONOO- interactions with lipids, DNA, and proteins via direct oxidative reactions or indirect, radical-mediated mechanisms have been implicated in various pathological events, such as stroke, myocardial infarction, diabetes, chronic heart failure, circulatory shock, chronic inflammatory diseases, and cancer (Pacher et al. 2007).

Peroxynitrite biosynthesis, synthesis, its oxidation and nitration reactions as well as reactions with various antioxidants have been summarized (for review, see Ducrocq et al. 1999; Hrabárová et al. 2007). Other papers have emphasized that $\mathrm{ONOO}^{-}$is actually one of the most reactive among the other reactive oxygen and nitrogen species having a potential to induce tissue damage during systemic inflammatory response and circulatory shock (Evgenov and Liaudet 2005). Also, biological significance of peroxynitrite, its precursors and reactions have been reported, including involvement of its cytotoxic action in various pathologies. The biomarker of the $\mathrm{ONOO}^{-}$reaction with protein tyrosines - 3-nitrotyro- sine formation has been identified e.g. in Lou Gehrig's and Parkinson's diseases, cancer, atherosclerosis, and in aging process (Kamat 2006).

The role which peroxynitrite plays in neurodegenerative inflammatory disorders including Alzheimer's disease, multiple sclerosis, amyotrophic lateral sclerosis, and the Parkinsonism dementia complex of Guam, has been reflected (Torreilles et al. 1999). Peroxynitrite has also been indicated to play an important role in regulating brain mitochondria function (Brookes et al. 1998). In fact, extra- or intra-mitochondrial $\mathrm{ONOO}^{-}$generation, its diffusion through mitochondrial compartments causing alteration in mitochondrial energy and calcium homeostasis, its fast, direct and free radical-dependent reactions with target biomolecule resulting in oxidation, nitration, and nitrosation of inner and outer membrane and intermembrane space, its fate, as well as signaling of cell death have been demonstrated (Radi et al. 2002).

Overview on the preferential protein targets of peroxynitrite and the role of proteins in its detoxifying pathways has been offered (Alvarez and Radi 2003). Possible mechanisms of $\mathrm{ONOO}^{-}$reaction pathways conferring to the proteins (hemoglobin, myoglobin, cytochrome $c$ ) and, especially, their scavenging role have been discussed (Pietraforte et al. 2003). Peroxynitrite as a potent cytotoxin plays a key role in the pathogenesis of cardiovascular dysfunction leading to progression of diabetic retinopathy, neuropathy, and nephropathy by attacking various biomolecules in vascular endothelium, vascular smooth muscle, and myocardium (Pacher and Szabó 2006).

\section{Free radicals in biological systems}

Though traditionally understood as deleterious prooxidants in biological environment, free radicals, due to their various redox actions, may play a key role in preventing biological systems from a variety of stress factors. They are formed and subsequently used to maintain homeostasis under physiological conditions. In vivo redox pathways mediated by reactive oxygen-, nitrogen- and thiol- species play pivotal roles in many physiological and pathological events, regarding intra- and inter-cellular signaling. Several free radicals, e.g. thiyl radical and nitrogen dioxide radical $\left({ }^{\circ} \mathrm{NO}_{2}\right)$ are known to promote cis-trans isomerization of double bonds of poly-unsaturated fatty acids. A trioxocarbonate anion radical $\left(\mathrm{CO}_{3}{ }^{--}\right)$is a potential oxidant of nucleic acids, e.g. guanine bases of DNA (Luc and Vergely 2008).

These highly reactive species are either oxygen-derived such as $\mathrm{O}_{2}{ }^{--}$, hydroxyl $\left({ }^{\circ} \mathrm{OH}\right), \mathrm{HOO}^{\bullet}$, and $\mathrm{CO}_{3}{ }^{--}$radicals or nitrogen-derived such as ${ }^{\circ} \mathrm{NO}$ and ${ }^{\circ} \mathrm{NO}_{2}$ radicals. The nonradical reactive metabolites are potential radical precursors, such as $\mathrm{H}_{2} \mathrm{O}_{2}, \mathrm{H}_{2} \mathrm{~S}, \mathrm{HOCl}$, singlet oxygen $\left({ }^{1} \mathrm{O}_{2}\right), \mathrm{O}_{3}$, and $\mathrm{ONOO}^{-}$(Ďuračková and Knasmüller 2007). 


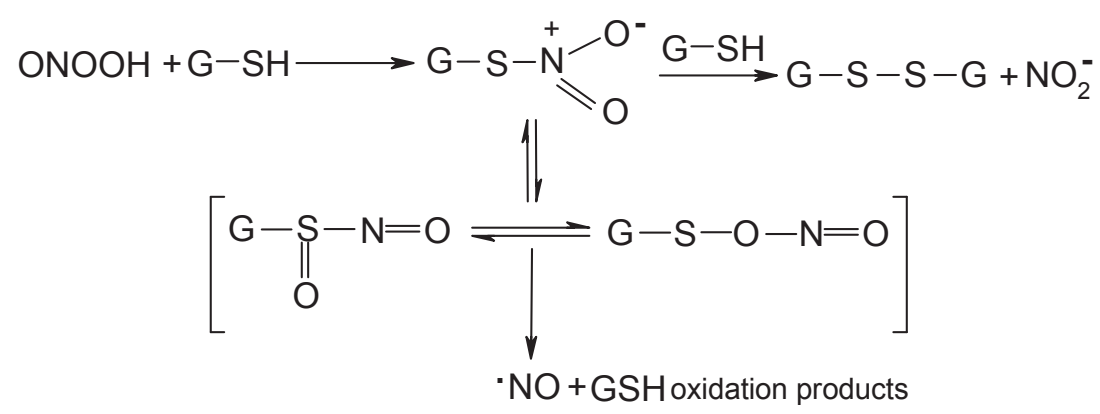

Figure 1. Proposed mechanism of nitric oxide radical formation via reaction of peroxynitrous acid and L-glutathione (Balazy et al. 1998).

Reactive oxygen and nitrogen species (RONS), the $\mathrm{ONOO}^{-}$precursors, have their origin either in endogenous sources (mitochondria, peroxisomes, NADPH oxidase, cytochrome P450, and xantine oxidoreductase system) or in exogenous sources (ultraviolet light, ionizing radiation, photochemical smog, xenobiotics, and environmental toxins) (Mangialasche et al. 2009).

\section{Anti-oxidative systems}

Thiol-based species, such as L-glutathione (GSH) and thioredoxin(s), functioning together with ascorbate (ASC) and $\alpha$-tocopherol (vitamin E), play a crucial role in in vivo preventing biological systems from oxidative and nitrosative damage (Fig. 1 and 2). Biological antioxidants can be classified according to their molecular size as either high-molar-mass: superoxide dismutase (SOD), catalase, GSH peroxidase, transferrin, albumin, polyphenols or lowmolar-mass compounds: ASC, GSH, uric acid, vitamin E, coenzyme Q (Ďuračková and Knasmüller 2007).

A natural flavonoid, quercetin, has been found as an efficient $\mathrm{ONOO}^{-}$scavenger mediating the reduction of 3-nitrotyrosine formation. Under biological conditions, $\mathrm{ONOO}^{-}$can be converted to nitrosothiols via the detoxification reaction in vivo thus regenerating ${ }^{\circ} \mathrm{NO}$ (Hayashi et al. 2004). In vivo, $\mathrm{ONOO}^{-}$is mostly trapped by substrates, such as thiols or metaloproteins through a bimolecular pathway, and, only its minor fraction is quickly converted into "radical-like" reactive species (Balavoine and Geletii 1999). Biomolecular pathways of $\mathrm{ONOO}^{-}$-mediated cell death and the role of ${ }^{\circ} \mathrm{NO}$ and $\mathrm{ONOO}^{-}$in cardiovascular pathophysiology have been outlined (Pacher et al. 2007).

Hemoglobin and myoglobin are involved in reversible $\mathrm{O}_{2}$ binding and transport in the blood or $\mathrm{O}_{2}$ storage in the muscle, respectively. They undergo several redox reactions to either scavenge toxic free radicals and RONS at oxidative stress, or in the case of brain-expressed neuroglobin, against pathogenic pathways connected with tissue hypoxia and ischemia, thus protecting neurons. The major contribution to the cellular damage is herein ascribed to the $\mathrm{ONOO}^{-}$formation (Herold and Fago 2005; Shivashankar 2006).

Among others, thiourea was reported to be one of the most effective $\mathrm{ONOO}^{-}$scavengers (Table 1) (Li et al. 1997). Inhibitory effects of various antioxidants (thiourea, mannitol, vinpocetine, propofol) on the hyaluronan depolymerization induced by ${ }^{\circ} \mathrm{OH}$ radicals, generated either by the system $\mathrm{H}_{2} \mathrm{O}_{2}$ plus $\mathrm{Cu}(\mathrm{II})$ or $\mathrm{ONOO}^{-}$, were demonstrated (Mendoza et al. 2007).

When extracellular ${ }^{\circ} \mathrm{NO}$ radical scavenging by quercetin was prevented by the action of SOD ${ }^{\circ} \mathrm{NO}$ bioactivity was increased (López-López et al. 2004). The ${ }^{\circledR} \mathrm{NO}$ radical scavenging and suppressing effects by catechins, the main constituents of green tea, were evaluated (Tsai et al. 2007).

\section{Nitric oxide radical, a peroxynitrite precursor}

Nitric oxide radical is a biologically ubiquitous lipophilic species. It was classified as a signaling, reactive free radical species, acting as a specific "messenger" in numerous biological processes (Symons 2000). Since it has been found out that

$$
\mathrm{ONOO}^{-}+\mathrm{CO}_{2} \rightleftharpoons \mathrm{ONOOCO}_{2}^{-} \stackrel{\mathrm{HAsc}^{-}}{\longrightarrow} \mathrm{Asc}^{\cdot-}+\mathrm{CO}_{3}^{2-}+\mathrm{H}^{+}+\cdot \mathrm{NO}_{2}
$$

Figure 2. Formation of ascorbyl anion radical and nitric dioxide radical via reaction of peroxynitrite anion and carbon dioxide in the presence of ascorbate anion (Kurz 2004). 


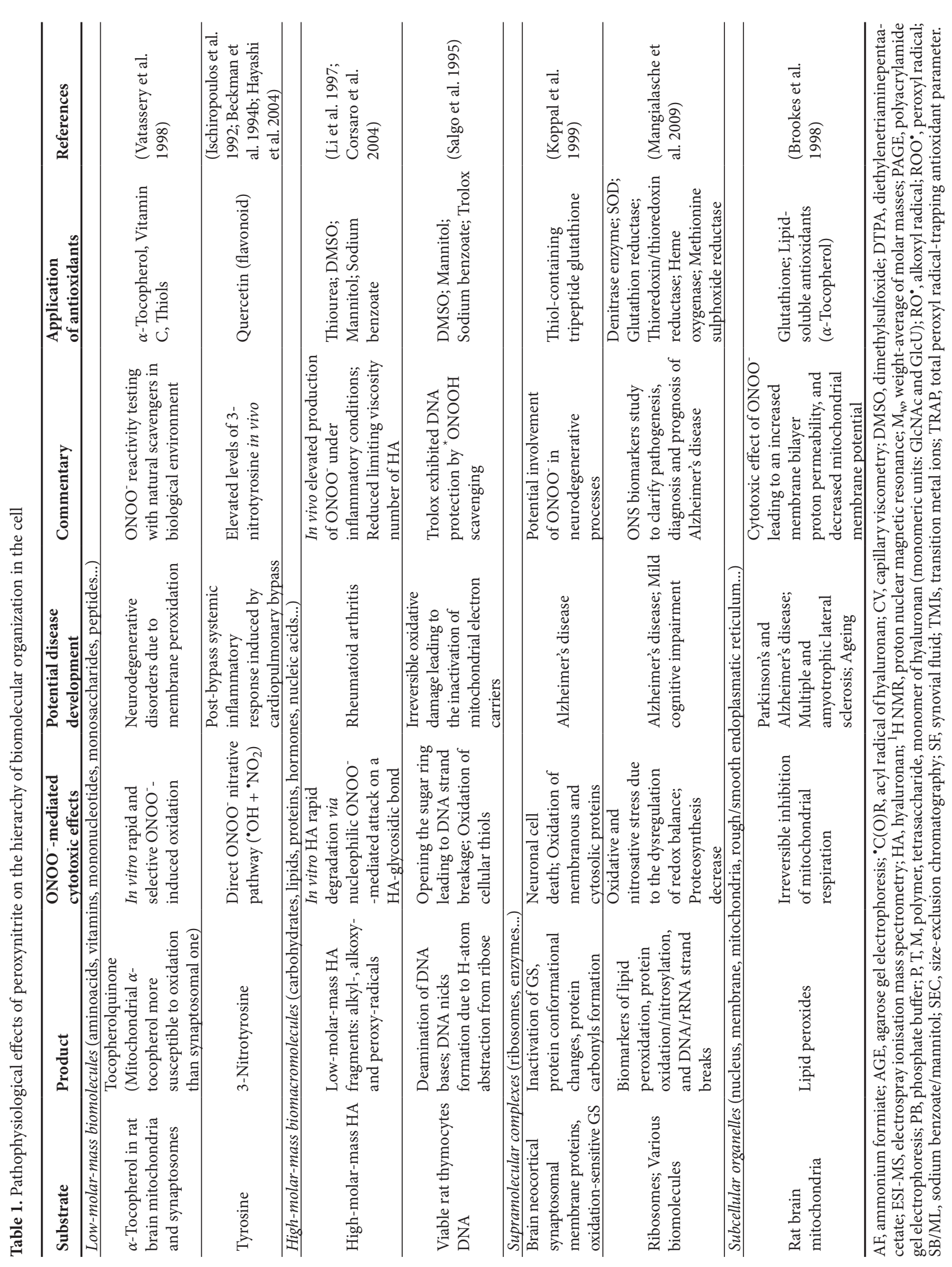




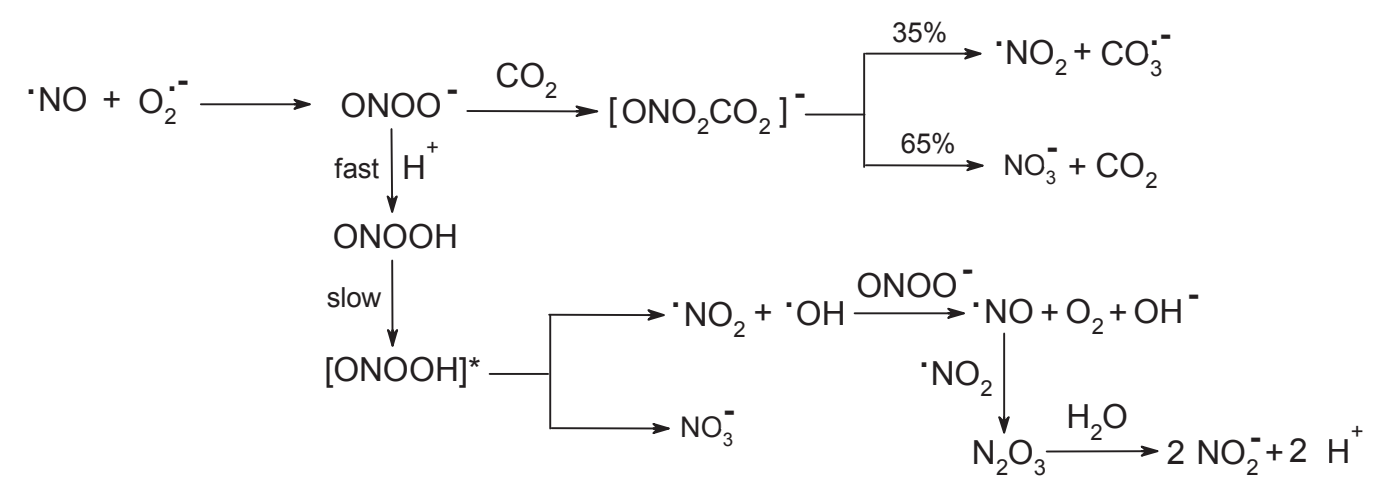

Figure 3. Hypothetical mechanism of various biomolecular pathways of peroxynitrite anion (Pfeiffer et al. 1997).

'NO serves as one of the key modulators of vascular tone in a role of endothelium-derived relaxing factor (EDRF), many studies were performed covering often unlike functions of 'NO. Activity of nitric oxide synthases (NOSs), a family of enzymes catalyzing production of ${ }^{\bullet} \mathrm{NO}$, has been found in most cell types (Pacher et al. 2007). In addition to the direct interactions of ${ }^{\bullet} \mathrm{NO}$ with signal transduction pathways of the cell, the specific reactions of $\mathrm{NO}$-derived products, such as $\mathrm{ONOO}^{-}$, with intra- and extracellular components may be responsible for damaging effects of ${ }^{\bullet} \mathrm{NO}$. Direct and indirect actions of ${ }^{\circ} \mathrm{NO}$ and its derivatives are quite diverse and depend primarily on concentration and cell type. Diffusion conditions of cellular oxidants $\left(\mathrm{O}_{2}{ }^{--},{ }^{\circ} \mathrm{NO}, \mathrm{ONOO}^{-}\right.$, and ${ }^{\circ} \mathrm{OH}$ ) have been demonstrated in detail (Pacher et al. 2007).

The most significant in vivo reaction of ${ }^{\bullet} \mathrm{NO}$ is its combination with $\mathrm{O}_{2}{ }^{\bullet-}$ (Fig. 3), released from several cellular sources, to form $\mathrm{ONOO}^{-}$. This species is relatively stable, however, its protonized form, peroxynitrous acid (ONOOH) undergoes rapid decay forming harmful ${ }^{\circ} \mathrm{OH}$ and ${ }^{\circ} \mathrm{NO}_{2}$ radicals.
-NO radical is synthesized in vivo by a variety of cell types, including macrophages, vascular endothelial cells, neutrophils, hepatocytes, phagocytes, and neurons. It is a major participant in several physiological functions such as blood pressure regulation (Hogg et al. 1992; Czapski and Goldstein 1995). Neutrophils and macrophages generate ${ }^{\circ} \mathrm{NO}$ via an L-arginine-dependent pathway (Fig. 4) (Jourd'heuil et al. 1997). Large quantities of ${ }^{\bullet} \mathrm{NO}$ are produced by the endothelial-constitutive form of NOS (ecNOS) and inducible form of NOS in neutrophils and monocytes upon inflammatory stimulation (Dawson and Dawson 1995; Conner and Grisham 1996; Hassan et al. 1998).

Evidence for the reaction of $\mathrm{ONOO}^{-}$with GSH giving an important biologically active metabolite, $S$-nitroglutathione, promoting a time-dependent production and oxidation of 'NO (Fig. 1) has been reported (Balazy et al. 1998). S-nitrosothiols are obtained via $S$-nitrosation of primary and secondary or tertiary thiols (Feelisch 1998). Hofstetter et al. (2007) claim that $S$-nitrosoglutathione (GSNO), generated in vivo, undergoes homolysis forming ${ }^{\circ} \mathrm{NO}$ and glutathionyl radical $\left(\mathrm{GS}^{\bullet}\right)$. However, no GSNO is produced reacting ${ }^{\bullet} \mathrm{NO}$<smiles>N=C(N)NCCC[C@H](N)C(=O)O</smiles>

L-Arginine

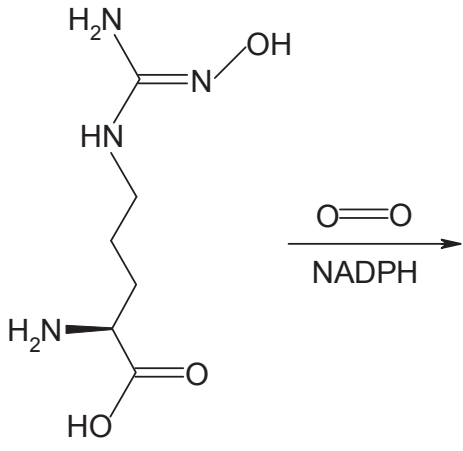

L-Hydroxyarginine

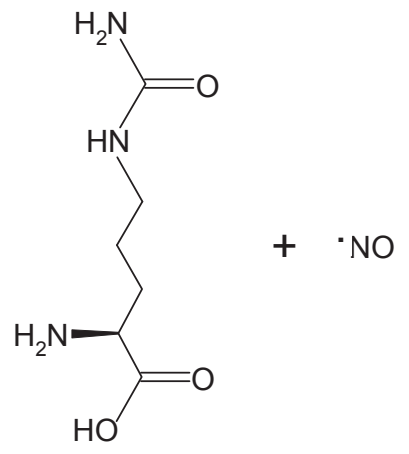

L-Citrulline

Figure 4. Nitric oxide radical production from amino acid L-arginine (Schönafinger 1999). 
with $\mathrm{GS}^{\bullet}$ for a very rapid intramolecular radical rearrangement of $\mathrm{GS}^{\bullet}$ to ${ }^{\bullet} \mathrm{GS}$, and, since the reaction of $\mathrm{GS}^{\bullet}$ with ${ }^{\bullet} \mathrm{NO}$ is very slow.

\section{Superoxide anion radical}

Superoxide anion radical is formed in neutrophils, monocytes, macrophages, and eosinophils due to the action of NADPH oxidase during a so-called "respiratory burst". NADPH oxidase, a highly regulated enzyme complex composed of a number of proteins, reduces oxygen to $\mathrm{O}_{2}{ }^{\bullet-}$ according to the reaction (1):

$$
2 \mathrm{O}_{2}+\mathrm{NADPH} \rightarrow 2 \mathrm{O}_{2}^{\bullet-}+\mathrm{NADP}^{+}+\mathrm{H}^{+}
$$

Another $\mathrm{O}_{2}{ }^{--}$source is xanthine oxido-reductase, also called xanthinoxidase. This molybdenum and iron-containing flavoprotein catalyzes oxidation of hypoxanthine to xanthine and then to uric acid. Molecular oxygen is the substrate and the products include $\mathrm{O}_{2}{ }^{\circ-}$. Other cellular sources for $\mathrm{O}_{2}{ }^{--}$are mitochondria in stressed cells, the formation of met-hemoglobin, and the reduction of oxygen by quinone radicals or by GSSG ${ }^{\bullet-}$ (Stern et al. 2007).

In situ generated $\mathrm{O}_{2}{ }^{\bullet-}$ undergoes a rapid spontaneous dismutation reaction (2) forming hydrogen peroxide, catalyzed by the SOD anti-oxidative enzyme family (Zhao et al. 2007):

$$
2 \mathrm{O}_{2}^{\bullet-}+2 \mathrm{H}^{+} \rightarrow \mathrm{H}_{2} \mathrm{O}_{2}+\mathrm{O}_{2}
$$

$\mathrm{O}_{2}{ }^{\bullet-}$ anion radical is a one-electron oxido-reductant. It does not have direct toxic effects on living targets; however, upon penetrating to important physiological sites, it is converted to hydrogen peroxide, ${ }^{1} \mathrm{O}_{2}$, and possibly to ${ }^{\circ} \mathrm{OH}$ radicals. Although $\mathrm{O}_{2}{ }^{--}$is unable to degrade hyaluronan on its own, it can participate in reactions with transition metal ions (3) to produce highly reactive and damaging species - ${ }^{\circ} \mathrm{OH}$ radicals (4). $\mathrm{O}_{2}{ }^{--}$anion radicals play also a decisive role by converting ${ }^{\circ} \mathrm{NO}$ to the powerful oxidant $\mathrm{ONOO}^{-}$ (Stern et al. 2007).

The iron-catalyzed Haber-Weiss reaction (5), which makes use of the Fenton chemistry (4), has been considered to be the major mechanism by which the highly reactive ${ }^{\circ} \mathrm{OH}$ radicals are generated in biological systems (Kehrer 2000).

$$
\begin{aligned}
& \mathrm{Fe}^{3+}+\mathrm{O}_{2}{ }^{--} \rightarrow \mathrm{Fe}^{2+}+\mathrm{O}_{2} \\
& \mathrm{Fe}^{2+}+\mathrm{H}_{2} \mathrm{O}_{2} \rightarrow \mathrm{Fe}^{3+}+{ }^{-} \mathrm{OH}+{ }^{\bullet} \mathrm{OH} \\
& \mathrm{O}_{2}{ }^{\bullet-}+\mathrm{H}_{2} \mathrm{O}_{2} \rightarrow \mathrm{O}_{2}+{ }^{-} \mathrm{OH}+{ }^{\bullet} \mathrm{OH}
\end{aligned}
$$

\section{Biosynthesis, fate and pathophysiological effects of peroxynitrite}

\section{Peroxynitrite - product of nitric oxide and superoxide reaction}

Peroxynitrite anion is generated in vivo by a fast radicalradical, diffusion-controlled, recombination reaction of $\mathrm{O}_{2}{ }^{\bullet-}$ and ${ }^{\bullet} \mathrm{NO}$. It exists in equilibrium with its protonized form - ONOOH $\left(\mathrm{p} K_{\mathrm{a}}=6.8\right)$ at physiological pH (Fig. 3). $\mathrm{ONOO}^{-}$is known to decay spontaneously with a short halflife of $1 \mathrm{~s}$. Therefore, it is rather difficult to assign its active concentration, which takes part in biochemical oxidations (Vatassery et al. 1998).

Various $\mathrm{ONOO}^{-}$-like conformational forms of sulfurbased analogues such as SNSS$^{-}$(Bojes et al. 1982), might be expected (Fig. 5). There have been reported only two possible planar conformations of $\mathrm{ONOO}^{-}$, 'cyclic'cis- and transform, both practically equal in energy (Symons 2000).

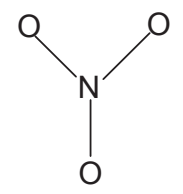

1

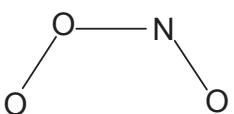

2

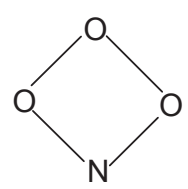

5

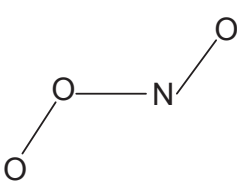

3

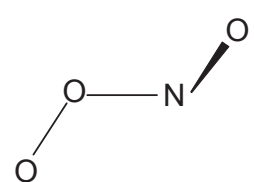

4

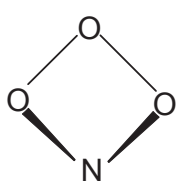

6

Figure 5. Various conformational alternatives for the peroxynitrite anion: 1, branched chain; 2, cis (planar open-chain); 3, trans (planar open-chain); 4, helical (nonplanar open-chain); 5, cyclic (planar chain); 6, bent (nonplanar chain) (Bojes et al. 1982). 
The role of transition metals on peroxynitrite functioning

The reactivity of peroxynitrite is highly $\mathrm{pH}$-dependent and is influenced by the presence of metals, thiols, and bicarbonate anion (Ischiropoulos et al. 1995). Reactions of peroxynitrite with thiols, transition metal ( $\mathrm{Fe}, \mathrm{Cu}, \mathrm{Mn}$ ) ions, carbon dioxide, tyrosine residues represent major pathways accounting for biological effects of this species (Ischiropoulos et al. 1992; Radi et al. 2001; Rodionov 2003). $\mathrm{Fe}(\mathrm{III})$ and $\mathrm{Cu}(\mathrm{II})$ catalyze heterolysis and react with peroxynitrite to form a potent nitrating agent with the reactivity of the nitryl cation, even when the metals are bound in proteins (Koppenol et al. 1992). Trace metals, particularly copper, in alkaline solutions, catalytically increase the rate of loss of peroxynitrite, at least $75 \%$, to nitrite and oxygen. EDTA addition inactivates the metal function by forming chelates (Edwards and Plumb 1994). As reported (Ducrocq et al. 1999), transition metals including Fe(III)-EDTA and $\mathrm{Cu} / \mathrm{Zn}$-SOD can catalyze peroxynitrite-mediated nitration of phenolic compounds. The kinetic study of Fe(III)EDTA-ONOO- and $\mathrm{Fe}(\mathrm{III})-\mathrm{EDTA}-\mathrm{H}_{2} \mathrm{O}_{2}$ model systems formation, as a function of $\mathrm{pH}$, was used with the aim to elucidate the iron speciation in natural waters as well as to understand the mechanism of oxygen activation by iron containing proteins (Sharma et al. 2010).

\section{Pathophysiology of biological structures}

Peroxynitrite is involved in pathogenesis of many diseases. A short overview on $\mathrm{ONOO}^{-}$-mediated pathophysiological processes is given in Table 1.

As to either direct cytotoxic oxidative/nitrosative or indirect peroxynitrite-derived radical-mediated interactions with cellular components and important target biomacromolecules, which may occur in vivo, protein oxidation and nitration are important features of $\mathrm{ONOO}^{-}$cytotoxicity. Peroxynitrite can cause chain scission of DNA promoting oxidation and nitration of DNA fragments finally resulting in the formation of 8-nitroguanine (Jourd'heuil et al. 1997).

Peroxynitrite damages via several distinctive mechanisms. First, it has direct toxic effects on all biomolecules and causes lipid peroxidation, protein oxidation, and DNA damage. The second mechanism involves the induction of several transcription factors leading to cytokine-induced chronic inflammation. Finally, it causes epigenetic perturbations that exaggerate nuclear factor $\kappa$-B mediated inflammatory gene expression. Lessons-learned from the treatment of several chronic disorders including pulmonary diseases suggest that chronic inflammation and glucocorticoid resistance are regulated by prolonged $\mathrm{ONOO}^{-}$production. The combination of elevated ${ }^{\circ} \mathrm{NO}$ plus excess $\mathrm{O}_{2}{ }^{\bullet-}$ with the formation of high levels of $\mathrm{ONOO}^{-}$is the proverbial intracellular "devil's triangle". The "devil's triangle" changes the nature of oxidative stress. Basically, every time ${ }^{\bullet} \mathrm{NO}$ and $\mathrm{O}_{2}{ }^{\bullet-}$ collide, they form $\mathrm{ONOO}^{-}$. $\mathrm{NO}$ is the only known biological molecule that reacts faster with $\mathrm{O}_{2}{ }^{\bullet-}$ and is produced in such high concentrations that it out-competes endogenous SOD; hence, the creation of the "devil's triangle" (for review, see Korkmaz et al. 2009).

Peroxynitrite is believed to act as a cytotoxic agent in the development of post-bypass systemic inflammatory response. $\mathrm{ONOO}^{-}$plays as well an important role in the pathogenesis of diabetic retinopathy, neuropathy, and nephropathy by attacking various biomolecules in vascular endothelium and vascular smooth muscle (Pacher and Szabó 2006).

Peroxynitrite functions in a manner of ${ }^{\bullet} \mathrm{OH}$ radical-like reactivity (Fig. 6). It directly oxidizes proteins yielding carbonyl species resulting in/due to the side-chain and peptide-bond cleavage. Formation of free or protein-bound 3-nitrotyrosine - an $\mathrm{ONOO}^{-}$biomarker in vivo - by tyrosine residues nitration (Crow and Beckman 1995; Shivashankar 2006) has proven alterations in protein functioning resulting in a changed catalytic activity, cell signaling and cytoskeletal organization (Schopfer et al. 2003). In addition, such modified proteins cannot be phosphorylated by tyrosine kinases (Martin et al. 1990).

If taken from a more specific viewpoint, a fundamental $\mathrm{ONOO}^{-}$reaction in biological systems is a rapid binding of carbon dioxide in equilibrium with bicarbonate anion under physiological conditions forming effective one-electron radical oxidants $-\mathrm{CO}_{3}{ }^{--}$and ${ }^{\circ} \mathrm{NO}_{2}$. They can readily oxidize amino acids (cysteine, tyrosine) yielding corresponding cysteinyl- or tyrosinyl radical species. Finally, nitrated products can be formed due to the diffusion-controlled termination reaction of ${ }^{-} \mathrm{NO}_{2}$ with biomolecule-derived radicals. Peroxynitrous acid can easily cross lipid bilayers and the products of its decay - ${ }^{\circ} \mathrm{OH}$ and ${ }^{\circ} \mathrm{NO}_{2}$ radicals - trigger lipid peroxidation as well as lipid and protein nitration at hydrophobic regions (Szabó et al. 2007).

The ${ }^{\circ} \mathrm{NO} / \mathrm{O}_{2}{ }^{- \text {- }}$ couple released from 3- $\mathrm{N}$-morpholinosydnonimine ( $\mathrm{SIN}-1)$ mediates a $\mathrm{CO}_{2}$-insensitive conversion of GSH to GSNO that activates soluble guanylyl cyclase - the major physiological target of sydnonimine-based vasodilators such as molsidomine - via trace metal-catalyzed release of ${ }^{\bullet} \mathrm{NO}$. Molsidomine is bioactivated in the liver via catalytic action of hepatic esterases resulting in the formation of SIN-1 (Schrammel et al. 1998). Monitoring the kinetics of $\mathrm{NADH}$ fluorescence quenching, using different buffer systems, showed that SIN-1 decomposition releasing $\mathrm{ONOO}^{-}$is carried out at various half-times. The $\mathrm{ONOO}^{-}$concentration maximum reached was $1.2-3.6 \%$ of applied sequential SIN-1 pulses. The method was used to simulate chronic exposure of cells or subcellular components to peroxynitrite (MartinRomero et al. 2004). 


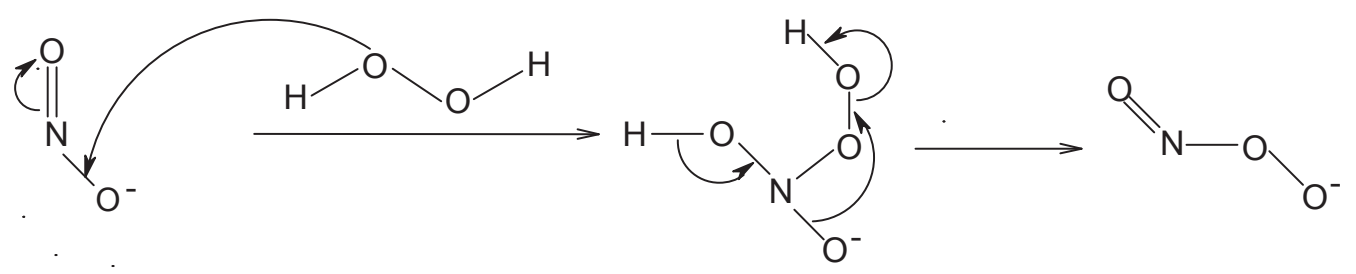

Figure 6. Baeyer-Villiger-like reaction scheme of peroxynitrite synthesis from sodium nitrite and acidified hydrogen peroxide.

\section{Peroxynitrite synthesis}

\section{Reaction of sodium nitrite and acidified hydrogen peroxide}

Peroxynitrite can be prepared by the most convenient, simple and possibly cleanest way (Saha et al. 1998) from sodium nitrite and acidified hydrogen peroxide according to the reaction (6) and (7). $\mathrm{ONOO}^{-}$can be synthesized at room temperature $\left(20^{\circ} \mathrm{C}\right)$ obtaining $170-185 \mathrm{mmol} / \mathrm{l}$ concentration with a yield of $\sim 85-95 \%$, with residual nitrite of $\sim 0.001 \%$ and residual $\mathrm{H}_{2} \mathrm{O}_{2}$ of $10-50 \%$. The $\mathrm{ONOO}^{-}$presence is indicated by a strong yellow color. The $\mathrm{ONOO}^{-}$concentration, as a function of its absorbance at $302 \mathrm{~nm}$, is assayed by absorption spectrophotometry using a standard value of molar extinction coefficient: $\varepsilon_{302}=1670(\mathrm{~mol} / \mathrm{l})^{-1} \cdot \mathrm{cm}^{-1}$.

$$
\begin{aligned}
& \mathrm{H}_{2} \mathrm{O}_{2}+\mathrm{HNO}_{2} \rightarrow \mathrm{ONOOH}+\mathrm{H}_{2} \mathrm{O} \\
& \mathrm{ONOOH}+\mathrm{OH}^{-} \rightarrow \mathrm{ONOO}^{-}+\mathrm{H}_{2} \mathrm{O}
\end{aligned}
$$

Baeyer-Villiger-like reaction mechanism of $\mathrm{ONOO}^{-}$synthesis has been proposed (Pfeiffer et al. 1997) yielding 80-100 $\mathrm{mmol} / \mathrm{l}$ alkaline $\mathrm{ONOO}^{-}$solutions.

Peroxynitrite was prepared using a quenched flow mixing reactor/stopped flow apparatus (Corsaro et al. 2004). A final $\mathrm{ONOO}^{-}$concentration $(170-220 \mathrm{mmol} / \mathrm{l})$, at a flow rate of
$26 \mathrm{ml} / \mathrm{min}$, was obtained; $\mathrm{NO}_{2}{ }^{-}, \mathrm{NO}_{3}{ }^{-}$and $\mathrm{H}_{2} \mathrm{O}_{2}$ are contaminants after reaction (Radi et al. 1991). Excess of $\mathrm{H}_{2} \mathrm{O}_{2}$ was removed by addition of solid $\mathrm{MnO}_{2}$. The treatment of the final solution with $\mathrm{MnO}_{2}$, however, leads to a $10-15 \%$ loss of the product.

\section{Peroxynitrite generation by SIN-1}

SIN-1, an in vivo ${ }^{\circ} \mathrm{NO}$ donor, is a mesoionic (mesomeric plus ionic), five-membered heterocyclic sydnone having a biological significance due to its planar aromatic structure and specific physico-chemical properties. It is a highly polarized compound with high dipole moment (Yelamaggad et al. 2005). SIN-1, a potent nitrovasodilator, simultaneously generates, in the presence of oxygen, via the non-enzymatic self-decomposition in situ ${ }^{\circ} \mathrm{NO}$ and $\mathrm{O}_{2}{ }^{\bullet-}$ (Andrekopoulos et al. 2004), in a $1: 1$ stoichiometry, which rapidly recombine to give $\mathrm{ONOO}^{-}(8)$ :

$$
{ }^{\bullet} \mathrm{NO}+\mathrm{O}_{2}^{\cdot-} \rightarrow \mathrm{ONOO}^{-}
$$

It is a three step mechanism (Fig. 7). As shown by several authors (Schrammel et al. 1998; Singh et al. 1999; Rojas Wahl 2004), in the first step, SIN-1 isomerises to an open ring at alkaline $\mathrm{pH}$ forming SIN-1A, in the second step SIN-1A undergoes one-electron oxidation to SIN-1 ${ }^{\bullet+}$ (SIN-1B)

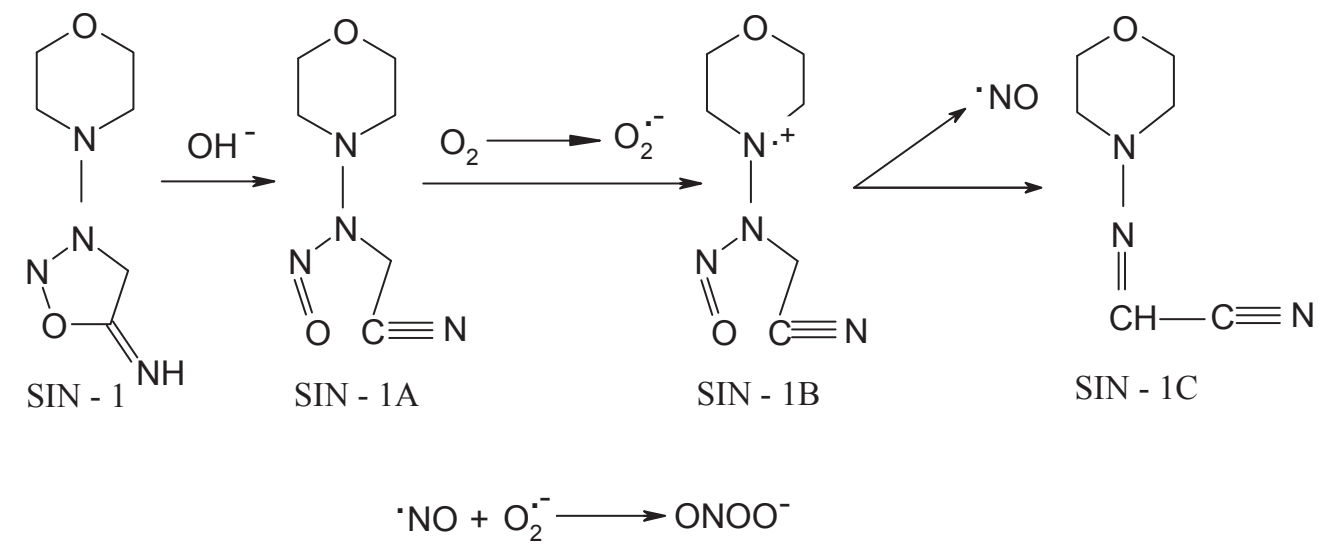

Figure 7. Peroxynitrite formation from SIN-1 (Hrabárová et al. 2007). 
generating $\mathrm{O}_{2}{ }^{- \text {- }}$ from $\mathrm{O}_{2}$. In the third step, $\mathrm{SIN}-1^{\bullet+}$ releases ${ }^{\circ} \mathrm{NO}$ and becomes inactive (SIN-1C). ${ }^{\circ} \mathrm{NO}$ recombines in an equimolar ratio with $\mathrm{O}_{2}{ }^{--}$to form $\mathrm{ONOO}^{-}$(Espey et al. 2002). SIN-1 probably behaves like an ${ }^{\circ} \mathrm{NO}$ donor in vivo and like an $\mathrm{ONOO}^{-}$donor in oxygenated buffer (Singh et al. 1999).

\section{Other methods used on peroxynitrite synthesis}

In Table 2, there are briefly summarized several methods used on $\mathrm{ONOO}^{-}$preparation. They are, in more detail, outlined (for review, see Hrabárová et al. 2007).

\section{Scission of glycosaminoglycans mediated by peroxynitrite}

Complex polysaccharides, glycosaminoglycans (GAGs), are widely distributed in the endothelial extracellular matrix (ECM) of tissues among which hyaluronan as well as heparin, heparan/keratan/dermatan/chondroitin sulfates have been the subject of an intensive study. They differ in their sugar composition, and, except for hyaluronan, in the position of the sulfate group as well as the degree of sulfation. They are typically heterogeneous in chain length and negatively charged. They also differ in the type of uronic acid, e.g. glucuronic or iduronic acid. A relatively anaerobic cartilage matrix is mainly composed of the two major protein groups, collagens and proteoglycans. Regulation of breakdown versus synthesis of these complex biopolymers consisting of a core protein with one or more covalently bound GAG chains specifies the cartilage matrix integral function. They contain large quantities of water via multiple hydrogen bonds and thus expanding their three-dimensional space (StefanovicRacic et al. 1993; Hassan et al. 1998).

Rheumatoid arthritis and osteoarthritis exist both as a consequence of the degradation of GAGs mostly via ${ }^{\circ} \mathrm{OH}$ radical action, the product of $\mathrm{ONOO}^{-}$decomposition. The -NO-mediated degradation of GAGs has two pathways. The first one is initiated by the conversion of nitric oxide to nitrous acid, while the second one includes $\mathrm{ONOO}^{-}$. Heparin and heparan sulfate are susceptible to degradation via nitrous acid, hyaluronan via $\mathrm{ONOO}^{-}$, and chondroitin sulfates partially via both reagents (Hassan et al. 1998). Decomposition of heparan sulfate and other GAGs of the extracellular matrix by ${ }^{\circ} \mathrm{NO}$ may be significant in pathophysiological situations (apoptosis, atherosclerotic plaque release, metastatic, inflammatory conditions) (Ghael et al. 1997). Endothelial-cell-derived ${ }^{\circ} \mathrm{NO}$ is capable of degrading heparin and heparan sulfate via $\mathrm{HNO}_{2}$ rather than $\mathrm{ONOO}^{-}$. Along with cleavage of the glycosidic bond, the amino and

Table 2. Representative pattern of various methods applied on peroxynitrite synthesis

\begin{tabular}{|c|c|c|c|c|}
\hline Precursors & Reaction type & Reaction mechanism & $\begin{array}{l}\mathrm{c}_{\text {ONOO- }} \\
(\mathrm{mol} / \mathrm{l})\end{array}$ & References \\
\hline $\mathrm{O}_{3}$ and $\mathrm{NaN}_{3}$ & $\begin{array}{l}\text { Reaction between ozone and sodium } \\
\text { azide }\left(\mathrm{H}_{2} \mathrm{O}_{2} \text { free ozonation }\right)\end{array}$ & $\mathrm{N}_{3}^{-}+2 \mathrm{O}_{3} \rightarrow \mathrm{ONOO}^{-}+\mathrm{N}_{2} \mathrm{O}+\mathrm{O}_{2}$ & $3.2-3.4 \times 10^{-2}$ & $\begin{array}{l}\text { (Kurz 2004; Al- } \\
\text { Assaf et al. 2003) }\end{array}$ \\
\hline $\begin{array}{l}\mathrm{NH}_{2} \mathrm{OH} / \mathrm{NH}_{2} \mathrm{Cl} / \\
\mathrm{Na}_{2} \mathrm{~N}_{2} \mathrm{O}_{3}\end{array}$ & Autoxidation of hydroxylamine & $\begin{array}{l}\mathrm{NH}_{2} \mathrm{OH}+\mathrm{O}_{2}+\mathrm{OH}^{-} \rightarrow \mathrm{H}_{2} \mathrm{O}_{2}+ \\
\mathrm{NO}^{-}+\mathrm{H}_{2} \mathrm{O} \\
\mathrm{NO}^{-}+\mathrm{O}_{2} \rightarrow \mathrm{ONOO}^{-}\end{array}$ & $3.3 \times 10^{-3}$ & $\begin{array}{l}\text { (Hughes and } \\
\text { Nicklin 1971) }\end{array}$ \\
\hline $\begin{array}{l}\text { Aqueous solution } \\
\text { of sodium/potassium } \\
\text { nitrate }\end{array}$ & $\begin{array}{l}\text { UV irradiation/photolysis } / \gamma \text { - } \\
\text { radiolysis of alkali metal nitrates }\end{array}$ & $\begin{array}{l}\text { Photons }(\lambda=254-280 \mathrm{~nm}) \\
\mathrm{Na}^{+} / \mathrm{K}^{+} \mathrm{NO}_{3}^{-} \rightarrow \mathrm{ONOO}^{-}\end{array}$ & $\begin{array}{l}\text { Not } \\
\text { mentioned }\end{array}$ & $\begin{array}{l}\text { (Edwards and } \\
\text { Plumb 1994) }\end{array}$ \\
\hline $\begin{array}{l}\mathrm{H}_{2} \mathrm{O}_{2} \text { and } \\
\left(\mathrm{CH}_{3}\right)_{2} \mathrm{CH}\left(\mathrm{CH}_{2}\right)_{2} \mathrm{NO}_{2}\end{array}$ & $\begin{array}{l}\text { Reaction of hydrogen peroxide } \\
\text { and isoamyl nitrite (Two-phase } \\
\text { nitrosation) }\end{array}$ & $\begin{array}{l}\mathrm{H}_{2} \mathrm{O}_{2} \text { and }\left(\mathrm{CH}_{3}\right)_{2} \mathrm{CH}\left(\mathrm{CH}_{2}\right)_{2} \mathrm{NO}_{2} \\
+\mathrm{OH}^{-} \rightarrow \mathrm{ONOO}^{-}+ \\
\left(\mathrm{CH}_{3}\right)_{2} \mathrm{CH}\left(\mathrm{CH}_{2}\right)_{2} \mathrm{OH}+\mathrm{H}_{2} \mathrm{O}\end{array}$ & 1.0 & $\begin{array}{l}\text { (Kurz 2004; Uppu } \\
\text { and Pryor 1996) }\end{array}$ \\
\hline $\mathrm{KO}_{2}$ and ${ }^{\circ} \mathrm{NO}$ & $\begin{array}{l}\text { Reaction of potassium superoxide } \\
\text { and nitric oxide aq. soln. }\end{array}$ & $\begin{array}{l}\mathrm{KO}_{2}+{ }^{\bullet} \mathrm{NO}+2 \mathrm{OH}^{-} \rightarrow \mathrm{ONOO}^{-}+ \\
\mathrm{H}_{2} \mathrm{O}_{2}+\mathrm{K}^{+}\end{array}$ & $7-11 \times 10^{-2}$ & (Khan et al. 2000) \\
\hline $\begin{array}{l}{\left[\mathrm{N}\left(\mathrm{CH}_{3}\right)_{4}\right]^{+}\left[\mathrm{O}_{2}{ }^{\bullet}\right]^{-} \text {and }} \\
\cdot \mathrm{NO}\end{array}$ & $\begin{array}{l}\text { NO preparation from sodium } \\
\text { nitrite and ferrous sulfate } \\
\text { Synthesis in liquid ammonia }\end{array}$ & $\begin{array}{l}2 \mathrm{NaNO}_{2}+\mathrm{FeSO}_{4}+2 \mathrm{H}_{2} \mathrm{O} \rightarrow 2^{\bullet} \mathrm{NO} \\
+\mathrm{Fe}^{3+}+\mathrm{SO}_{4}^{2-}+2 \mathrm{Na}^{+}+4 \mathrm{OH}^{-} \\
{\left[\mathrm{N}\left(\mathrm{CH}_{3}\right)_{4}\right]^{+}\left[\mathrm{O}_{2}{ }^{-}\right]^{-}+{ }^{\circ} \mathrm{NO}(\mathrm{g})+} \\
\mathrm{NH}_{3}(\mathrm{l}) \rightarrow\left[\mathrm{N}\left(\mathrm{CH}_{3}\right)_{4}\right]^{+}[\mathrm{ONOO}]^{-}\end{array}$ & $0.162^{*}$ & $\begin{array}{l}\text { (Kurz 2004; } \\
\text { Bohle et al. 2004) }\end{array}$ \\
\hline $\begin{array}{l}\mathrm{H}_{2} \mathrm{O}_{2} \text { and } \\
\mathrm{CH}_{3} \mathrm{CH}_{2} \mathrm{O}\left(\mathrm{CH}_{2}\right)_{2} \mathrm{NO}_{2}\end{array}$ & $\begin{array}{l}\text { Reaction of nucleophiles with alkyl } \\
\text { (2-ethoxyethyl) nitrites }\end{array}$ & $\begin{array}{l}\mathrm{CH}_{3}-\mathrm{CH}_{2}-\mathrm{O}-\mathrm{CH}_{2}-\mathrm{CH}_{2}-\mathrm{ONO}+ \\
\mathrm{HOO}^{-} \rightarrow \mathrm{CH}_{3}-\mathrm{CH}_{2}-\mathrm{O}_{-}-\mathrm{CH}_{2}-\mathrm{CH}_{2}^{-} \\
\mathrm{OH}+\mathrm{ONOO}^{-}\end{array}$ & $1.5-6 \times 10^{-2}$ & (Leis et al. 1993) \\
\hline${ }^{\circ} \mathrm{NO}$ and alkaline $\mathrm{H}_{2} \mathrm{O}_{2}$ & $\begin{array}{l}\text { NO preparation from nitrosyl- } \\
\text { sulfuric acid } \\
\text { Alkaline nitrosation of hydrogen } \\
\text { peroxide }\end{array}$ & $\begin{array}{l}2 \mathrm{HNOSO}_{4}+\mathrm{H}_{2} \mathrm{O} \rightarrow 2 \mathrm{H}_{2} \mathrm{SO}_{4}+ \\
{ }^{\circ} \mathrm{NO}+\mathrm{NO}_{2} \\
2 \mathrm{HOO}^{-}+2 \mathrm{OH}^{-}+{ }^{-} \mathrm{NO} \rightarrow \mathrm{ONOO}^{-} \\
+2 \mathrm{H}_{2} \mathrm{O}+\mathrm{O}_{2}\end{array}$ & $5-60 \times 10^{-4}$ & $\begin{array}{l}\text { (Petriconi and } \\
\text { Papee 1966) }\end{array}$ \\
\hline
\end{tabular}

*the value expressed in grams. 
sulfate groups are both eliminated. Inflammatory processes may be responsible for release of excess ${ }^{\circ} \mathrm{NO}$ and $\mathrm{O}_{2}{ }^{\bullet}$, forming $\mathrm{ONOO}^{-}$capable to degrade hyaluronan but not heparan sulfate. The balance between ${ }^{\circ} \mathrm{NO}$ and $\mathrm{O}_{2}{ }^{- \text {- }}$ determines which GAG component of the ECM is destroyed and it may be important in regulating the disease processes (Darley-Usmar et al. 1995; Vilar et al. 1997).

\section{Hyaluronan susceptibility to peroxynitrite oxidative action}

Hyaluronan is a linear/non-branched glycosaminoglycan bearing no sulfate groups, composed of alternating disaccharide units: d-glucuronic acid (GlcU) and $N$-acetyl-d-glucosamine (GlcNAc). It is a naturally occurring biopolymer widely distributed in vertebrate tissues. Aqueous hyaluronan solutions $\left(\mathrm{p} K_{\mathrm{a}}=3.2\right)$ are represented by negatively charged macromolecules exhibiting a three-dimensional structure with extensive intramolecular hydrogen bonding. Highly viscous hyaluronan solutions - with average molar mass $\left(10^{6}-10^{7} \mathrm{Da}\right)$ - have gel-like properties at the concentration range of $2-4 \mathrm{mg} / \mathrm{ml}$ in the synovial fluid, in which it serves also as the joint-lubricating agent (Šoltés et al. 2006).

At neutral $\mathrm{pH}$, decomposition products of the probably more reactive trans-ONOO${ }^{-}$, released from a complex radical pair $\left[{ }^{\circ} \mathrm{OH}-\mathrm{ONO}^{\bullet}\right.$ ], ${ }^{\bullet} \mathrm{NO}_{2}$ and ${ }^{\bullet} \mathrm{OH}$ radicals, degrade hyaluronan ( $\mathrm{Li}$ et al. 1997; Vilar et al. 1997; Hassan et al. 1998), as depicted in Fig. 8. The polymeric chains are predominantly cleaved by ${ }^{\circ} \mathrm{OH}$ radicals. The concentration of hyaluronan fragments has a progressive tendency, which is linear with $\mathrm{ONOO}^{-}$concentration up to $0.15 \mathrm{mmol} / \mathrm{l}$. It reaches $4 \mu \mathrm{mol} / 1$ at high $\mathrm{ONOO}^{-}$concentration. Each $\mathrm{ONOO}^{-}$molecule generates $1.12 \times 10^{-2}$ hyaluronan chain breaks resulting in reduced solution viscosity (Al-Assaf et al. 2003). Protective scavengers against deleterious action of RONS on this biopolymer might be e.g. thiourea (extremely effective), dimethyl sulfoxide (moderately effective), sodium benzoate and mannitol (slightly effective).

$\mathrm{ONOO}^{-}$exhibits ${ }^{\bullet} \mathrm{OH}$ radical-like reactivity derived from the vibrationally exciting state of probably less stable transONOOH (Tsai et al. 1994). Hyaluronan does not undergo the degradation by ${ }^{\circ} \mathrm{NO}$ and $\mathrm{HNO}_{2}$ due to a protective effect of its $N$-acetyl groups (Vilar et al. 1997). At acidic $\mathrm{pH}, \mathrm{ONOO}^{-}$-dependent $\mathrm{C}$-centered carbon radicals are formed in monomers, in the tetrasaccharide as well as in the hyaluronan polymer, as revealed by spin-trapping electron paramagnetic resonance (EPR) spectroscopic experiments. This fact supports the hypothesis of oxidative pathway involved in the degradation of hyaluronan playing a key role in the development and progression of rheumatoid arthritis (Corsaro et al. 2004). $\mathrm{CO}_{3}{ }^{\circ-}$ anion radical, the product of the biologically relevant reaction of $\mathrm{ONOO}^{-}$with carbon dioxide, causes $\sim 20 \%$ yields of hyaluronan chain scission $v i a$ not well-known mechanism (Al-Assaf et al. 2006).

It was shown that hyaluronan ameliorates osteoarthritis chondrocyte protection against oxidative stress caused by exposure to a genotoxic $\mathrm{ONOO}^{-}$-induced mitochondrial DNA damage. The biopolymer enhances the DNA repair, chondrocyte viability, preserves ATP levels in primary chondrocytes, and protects them from cytokine-induced mitochondrial DNA damage as well as from mitochondriadriven apoptosis (Grishko et al. 2009).

Monitoring the kinetics of oxidative degradation of hyaluronan applying a synthetically prepared $\mathrm{ONOO}^{-}$solution containing residual $\mathrm{H}_{2} \mathrm{O}_{2}$ or $\mathrm{H}_{2} \mathrm{O}_{2}$-free $\mathrm{ONOO}^{-}$solution, respectively, via rotational viscometry was reported (Stankovská et al. 2006). Various investigations on $\mathrm{ONOO}^{-}$prooxidative action resulting in hyaluronan fragmentation are summarized in Table 3.

As to the investigation on oxidative degradation of high-molar-mass hyaluronan by reactive free radicals, an overview (Šoltés et al. 2006) has been provided on currently used analytical methods to evaluate the impact of different

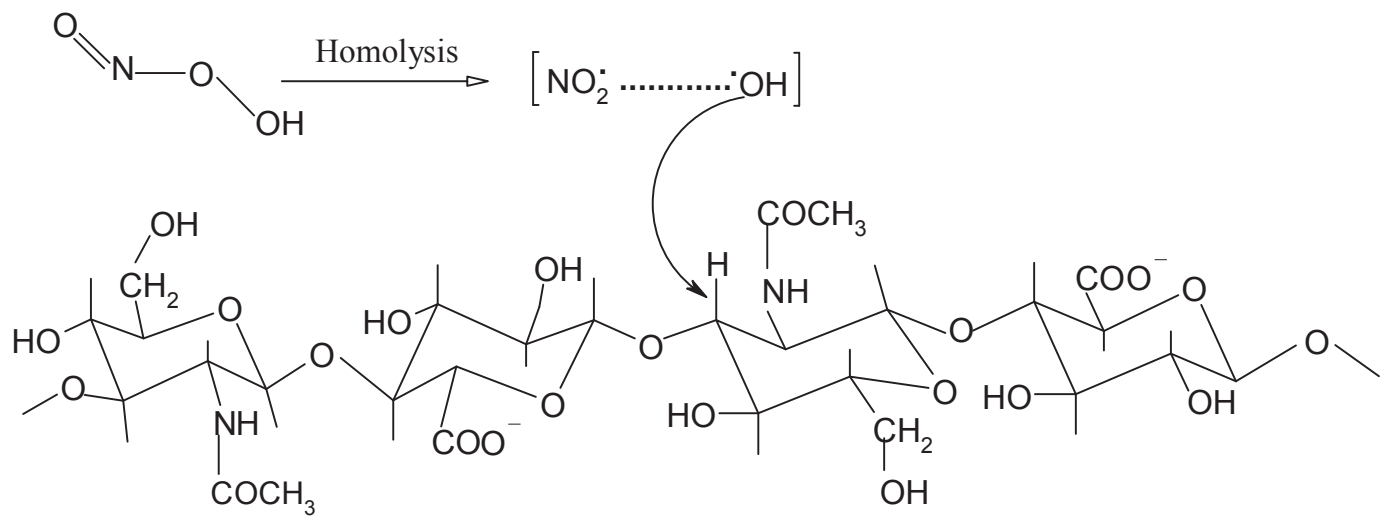

Figure 8. Hyaluronan attack mediated by peroxynitrite. 


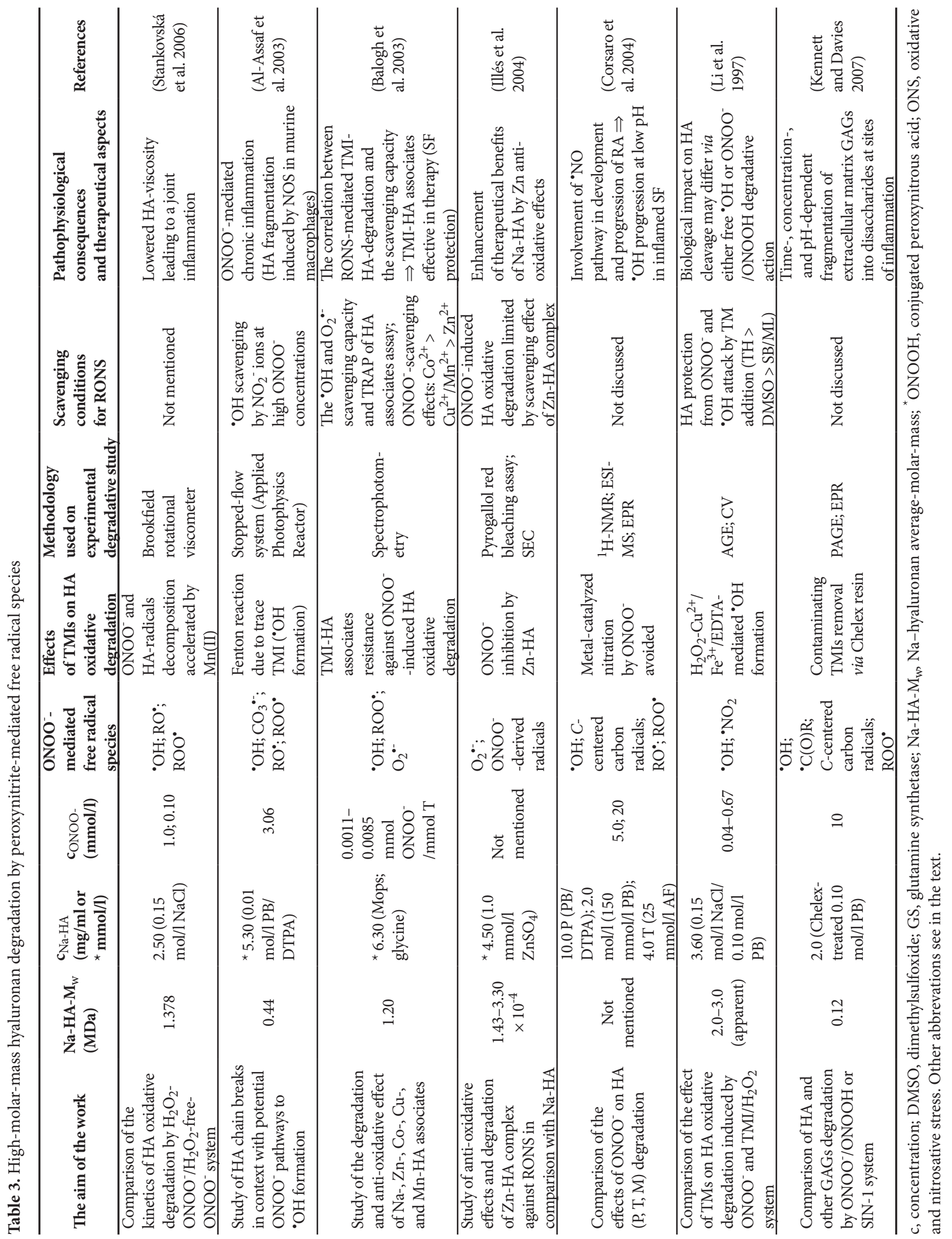


effects of RONS on oxidative degradation of high-molarmass hyaluronan resulting in the alterations of its structure (chain size, molar mass and solution viscosity reduction). Hyaluronans are well-characterized by their molar mass distribution via viscometry and light scattering.

Rheological parameters - markers of hyaluronan oxidative degradation can be detected via capillary or rotational viscometry. Capillary viscometry-based Mark-Houwink equation was used (Gura et al. 1998) to characterize hyaluronan fragments after being undergone to ultrasonical degradation.

Chemical modification of hyaluronan monosaccharide units after their oxidative degradation due to the action of free radicals is best characterized by EPR method. Indeed, identification of the generation of free radicals as a consequence of anti- or pro-oxidative action of d-penicillamine in the degradative system \{hyaluronan plus ASC plus $\mathrm{Cu}(\mathrm{II})\}$ was recently monitored via EPR method (Valachová et al. 2009). Al-Assaf et al. (1999) used EPR method to study the formation of various radicals in the reaction of the $\mathrm{Ti}$ (III) plus $\mathrm{H}_{2} \mathrm{O}_{2}$ system-generating ${ }^{\bullet} \mathrm{OH}$ radicals with hyaluronan. Their results support the thesis that each ${ }^{\circ} \mathrm{OH}$ radical action may result in a single hyaluronan chain scission. Thus, hyaluronan radicals were identified at the $C_{5}(\mathrm{GlcU})$ and $C_{6}$ (GlcNAc) moieties.

Pro- or anti-oxidative effects of potential low-molar-mass thiol-based scavengers of ${ }^{\bullet} \mathrm{OH}$ radicals, d-penicillamine and GSH, were studied monitoring the kinetics of hyaluronan oxidative degradation by the Weissberger's system \{ASC plus $\mathrm{Cu}(\mathrm{II})\}$ using rotational viscometry. Fragmented hyaluronan samples were also tested by non-isothermal chemiluminescence method revealing effects of these thiols on decomposition of hydroperoxides and removal of oxygenated structures. Fourier-transformed infrared spectroscopy indicated possible thiol incorporation into hyaluronan biopolymer (Hrabárová et al. 2009).

\section{Biomedical and therapeutical importance}

The research on ubiquitous endobiotics, playing important role in biological systems, such as nitric oxide radical and peroxynitrite, has recently led to a numerous publication activity meeting all aspects of physiological and pathological areas of interest.

Because oxidative stress plays a key role in the pathogenesis of cancer and many metabolic diseases, an effective antioxidant therapy would be of great importance in these circumstances. Nevertheless, convincing randomized clinical trials revealed that antioxidant supplementations were not associated with significant reduction in incidence of cancer, chronic diseases, and all-cause mortality. As oxidation of essential molecules continues, it turns to nitro-oxidative stress because of the involvement of nitric oxide in pathogenesis processes (for review, see Korkmaz et al. 2009).

A possible explanation for the potential negative effect of antioxidant supplements might be that RONS in moderate concentrations are essential mediators of reactions by which the body gets rid of unwanted cells. Thus, if administration of antioxidant supplements decreases free radicals, it may interfere with essential defensive mechanisms for ridding the organism of damaged cells, including those that are injured, precancerous and cancerous (Linnane et al. 2007).

Detrimental $\mathrm{ONOO}^{-}$effects, during its over-production, exacerbated via its reaction with carbon dioxide may result even in a redirection of $\mathrm{ONOO}^{-}$specificity. Surprisingly, besides this, $\mathrm{ONOO}^{-}$exhibits significant biomedical effects - protective effect i) at high concentrations - it behaves as anti-viral, anti-microbial, and anti-parasitic agent, and ii) at low concentrations, it stimulates protective mechanisms in the cardiovascular, nervous, and respiratory systems (Ascenzi et al. 2010).

There are several commercial drugs with a direct $\mathrm{ONOO}^{-}$ -scavenging potential. Despite this, most of them preferentially exhibit an indirect $\mathrm{ONOO}^{-}$-derived secondary radicaldetoxification activity in vitro. Many classical therapeuticals have, however, less effectivity in the $\mathrm{ONOO}^{-}$deactivation in vivo for their quite low rate constants (Szabó et al. 2007). It is worth of mentioning that e.g. acetaminophen has been proven to attenuate $\mathrm{ONOO}^{-}$-induced matrix metalloproteinase activity and related cardiotoxicity (Rork et al. 2006). A typical inhibitor/chelator of iron-dependent formation of -OH radicals - desferoxamine - has been also confirmed as an effective inhibitor of the $\mathrm{ONOO}^{-}$-mediated oxidation and nitration via reaction with the $\mathrm{CO}_{3}{ }^{\circ-}$ and ${ }^{\circ} \mathrm{NO}_{2}$ radicals (Bartesaghi et al. 2004). What is speculative/intriguing, tyrosinecontaining peptides can also play a role of $\mathrm{ONOO}^{-}$-derived radical scavengers at the cellular level. They may function as good neutralizers of the cytotoxic effects of exogenous and endogenous $\mathrm{ONOO}^{-}$, inhibiting thus its pro-apoptotic effect on neurons (Ye et al. 2007). Pharmacological strategies to attenuate the toxic effects of peroxynitrite have been, in present, focused on the catalytic reduction of this species to nitrite and its isomerization to nitrate by metalloporphyrins - exogenous $\mathrm{ONOO}^{-}$scavengers - potential candidates for drug development for cardiovascular, inflammatory, and neurodegenerative diseases. These decomposition catalysts can be effectively applied as therapeutics for $\mathrm{ONOO}^{-}$-induced pathology (Szabó et al. 2007).

Enormous challenge still remains to reduce a disease derived-human suffering if a biological specificity against deleterious actions of oxidants in living systems is better understood. A special interest has to be focused on experimental investigations elucidating specific cellular mechanisms such as the effects of oxidative and nitrosative stress in the respiratory systems, signaling pathways of reactive radical species as 
well as the role of anti-oxidative systems. The management of the pathogenesis of various diseases may eventually lead to discovery of novel therapeutical and clinical strategies.

Acknowledgements. The work was in part supported by the VEGA grant project Nos.: 2/0115/09, 2/0083/09, 2/0056/10, 2/0011/11 of the Slovak Academy of Sciences. This contribution is the result of implementation and realization of the projects ITMS-26220120054 and ITMS-26240220040 supported by the Research \& Development Operational Programme funded by the ERDF.

\section{References}

Al-Assaf S., Hawkins C. L., Parsons B. J., Davies M. J., Phillips G. O. (1999): Identification of radicals from hyaluronan (hyaluronic acid) and cross-linked derivatives using electron paramagnetic resonance spectroscopy. Carbohydr. Polym. 38, 17-22 doi:10.1016/S0144-8617(98)00084-8

Al-Assaf S., Navaratnam S., Parsons B. J., Phillips G. O. (2003): Chain scission of hyaluronan by peroxynitrite. Arch. Biochem. Biophys. 411, 73-82 doi:10.1016/S0003-9861(02)00724-5

Al-Assaf S., Navaratnam S., Parsons B. J., Phillips G. O. (2006): Chain scission of hyaluronan by carbonate and dichloride radical anions: Potential reactive oxidative species in inflammation? Free Radic. Biol. Med. 40, 2018-2027 doi:10.1016/j.freeradbiomed.2006.01.033

Alvarez B., Radi R. (2003): Peroxynitrite reactivity with amino acids and proteins. Amino Acids 25, 295-311 doi:10.1007/s00726-003-0018-8

Andrekopoulos C., Zhang H., Joseph J., Kalivendi S., Kalyanaraman B. (2004): Bicarbonate enhances a-synuclein oligomerization and nitration: intermediacy of carbonate radical anion and nitrogen dioxide radical. Biochem. J. 378, 435-447 doi:10.1042/BJ20031466

Ascenzi P., di Masi A., Sciorati C., Clementi E. (2010): Peroxynitrite - an ugly biofactor? BioFactors 36, 264-273 doi:10.1002/biof.103

Balavoine G. G. A., Geletii Y. V. (1999): Peroxynitrite scavenging by different antioxidants. Part I: Convenient assay. Nitric Oxide 3, 40-54 doi:10.1006/niox.1999.0206

Balazy M., Kaminski P. M., Mao K., Tan J., Wolin M. S. (1998): $\mathrm{S}$-nitroglutathione, a product of the reaction between peroxynitrite and glutathione that generates nitric oxide. J. Biol. Chem. 273, 32009-32015 doi:10.1074/jbc.273.48.32009

Balogh G. T., Illés J., Székely Z., Forrai E., Gere A. (2003): Effect of different metal ions on the oxidative damage and antioxidant capacity of hyaluronic acid. Arch. Biochem. Biophys. 410, 76-82 doi:10.1016/S0003-9861(02)00661-6

Bartesaghi S., Trujillo M., Denicola A., Folkes L., Wardman P., Radi R. (2004): Reactions of desferrioxamine with peroxynitritederived carbonate and nitrogen dioxide radicals. Free Radic. Biol. Med. 36, 471-483 doi:10.1016/j.freeradbiomed.2003.10.011
Beckman J. S., Ye Y. Z., Anderson P. G., Chen J., Accavitti M. A., Tarpey M. M., White C. R. (1994a): Extensive nitration of protein tyrosines in human atherosclerosis detected by immunohistochemistry. Biol. Chem. Hoppe-Seyler 375, 81-88 doi:10.1515/bchm3.1994.375.2.81

Beckman J. S., Chen J., Ischiropoulos H., Crow J. P. (1994b): Oxidative chemistry of peroxynitrite. Methods Enzymol. 233, 229-240 doi:10.1016/S0076-6879(94)33026-3

Bohle D. S., Sagan E. S. (2004): Tetramethyammonium salts of superoxide and peroxynitrite. Inorg. Synth. 34, 36-42

Bojes J., Chivers T., Laidlaw W. G., Trsic M. (1982): The thio analog of peroxynitrite, [SSNS]-: preparation, electronic structure, resonance Raman spectrum, and formation of complexes with nickel and cobalt. J. Am. Chem. Soc. 104, 4837-4841 doi:10.1021/ja00382a017

Brookes P. S., Land J. M., Clark J. B., Heales S. J. R. (1998): Peroxynitrite and brain mitochondria: evidence for increased proton leak. J. Neurochem. 70, 2195-2202 doi:10.1046/j.1471-4159.1998.70052195.x

Conner E. M., Grisham M. B. (1996): Inflammation, free radicals, and antioxidants. Nutrition 12, 274-277 doi:10.1016/S0899-9007(96)00000-8

Corsaro M. M., Pietraforte D., Di Lorenzo A. S., Minetti M., Marino G. (2004): Reaction of peroxynitrite with hyaluronan and related saccharides. Free Radic. Res. 38, 343-353 doi:10.1080/10715760310001653833

Crow J. P., Beckman J. S. (1995): The role of peroxynitrite in nitric oxide-mediated toxicity. Curr. Top. Microbiol. Immunol. 196, $57-73$

Czapski G., Goldstein S. (1995): NO with superoxide and oxygen in biological systems: a kinetic approach. Free Radic. Biol. Med. 19, 785-794 doi:10.1016/0891-5849(95)00081-8

Darley-Usmar V., Wiseman H., Halliwell B. (1995): Nitric oxide and oxygen radicals: a question of balance. FEBS Lett. 369, $131-135$ doi:10.1016/0014-5793(95)00764-Z

Dawson T. M., Dawson V. L. (1995): Nitric oxide: actions and pathological roles. The Neuroscientist 1, 7-18 doi: $10.1177 / 107385849500100103$

Ducrocq C., Blanchard B., Pignatelli B., Ohshima H. (1999): Peroxynitrite: an endogenous oxidizing and nitrating agent. Cell Mol. Life Sci. 55, 1068-1077 doi:10.1007/s000180050357

Duračková Z., Knasmüller S. (2007): The Activity of Natural Compounds in Diseases Prevention and Therapy. (Eds. Z. Duračková and S. Knasmüller). Slovak Academic Press, Bratislava, Slovak Republic

Edwards J. O., Plumb R. C. (1994): The chemistry of peroxonitrites. Progr. Inorg. Chem. 41, 599-635 doi:10.1002/9780470166420.ch8

Espey M. G., Xavier S., Thomas D. D., Miranda K. M., Wink D. A. (2002): Direct real-time evaluation of nitration with green fluorescent protein in solution and within human cells reveals the impact of nitrogen dioxide vs. peroxynitrite mechanisms. Proc. Natl. Acad. Sci. U.S.A. 99, 3481-3486 doi:10.1073/pnas.062604199 
Evgenov O. V., Liaudet L. (2005): Role of nitrosative stress and activation of poly(ADP-ribose) polymerase-1 in cardiovascular failure associated with septic and hemorrhagic shock. Curr. Vasc. Pharmacol. 3, 293-299 doi:10.2174/1570161054368580

Feelisch M. (1998): The use of nitric oxide donors in pharmacological studies. Naunyn-Schmiedeberg's Arch. Pharmacol. 358, 113-122 doi:10.1007/PL00005231

Ghael D., Mileva M., Dweck H. S., Rosenfeld L. (1997): The nitric oxide donor S-nitroso-N-acetyl-D,L-penicillamine degrades heparan sulfate and heparin. Biochem. Mol. Biol. Int. 43, $183-188$

Grishko V., Xu M., Ho R., Mates A., Watson S., Kim J. T., Wilson G. L., Pearsall A. W. 4th (2009): Effects of hyaluronic acid on mitochondrial function and mitochondria-driven apoptosis following oxidative stress in human chondrocytes. J. Biol. Chem. 284, 9132-9139 doi:10.1074/jbc.M804178200

Gura E., Hückel M., Müller P.-J. (1998): Specific degradation of hyaluronic acid and its rheological properties. Polym. Degrad. Stab. 59, 297-302 doi:10.1016/S0141-3910(97)00194-8

Hassan M. S., Mileva M. M., Dweck H. S., Rosenfeld L. (1998): Nitric oxide products degrade chondroitin sulfates. Nitric Oxide 2, 360-365 doi:10.1006/niox.1998.0198

Hayashi Y., Sawa Y., Nishimura M., Fukuyama N., Ichikawa H., Ohtake S., Nakazawa H., Matsuda H. (2004): Peroxynitrite, a product between nitric oxide and superoxide anion, plays a cytotoxic role in the development of post-bypass systemic inflammatory response. Eur. J. Cardiothorac. Surg. 26, 276-280 doi:10.1016/j.ejcts.2004.03.033

Herold S., Fago A. (2005): Reactions of peroxynitrite with globin proteins and their possible physiological role. Comp. Biochem. Physiol., Part A. 142, 124-129

Hofstetter D., Nauser T., Koppenol W. H. (2007): The glutathione thiyl radical does not react with nitrogen monoxide. Biochem. Biophys. Res. Commun. 360, 146-148 doi:10.1016/j.bbrc.2007.06.008

Hrabárová E., Gemeiner P., Šoltés L. (2007): Peroxynitrite: In vivo and in vitro synthesis and oxidant degradative action on biological systems regarding biomolecular injury and inflammatory processes. Chem. Pap. 61, 417-437 doi:10.2478/s11696-007-0058-8

Hrabárová E., Valachová K., Rychlý J., Rapta P., Sasinková V., Malíková M., Šoltés L. (2009): High-molar-mass hyaluronan degradation by Weissberger's system: Pro- and anti-oxidative effects of some thiol compounds. Polym. Degrad. Stab. 94, 1867-1875 doi:10.1016/j.polymdegradstab.2009.05.007

Hogg N., Darley-Usmar V. M., Wilson M. T., Moncada S. (1992): Production of hydroxyl radicals from the simultaneous generation of superoxide and nitric oxide. Biochem. J. 281, 419-424

Hughes M. N., Nicklin H. G. (1971): Autoxidation of hydroxylamine in alkaline solutions. J. Chem. Soc. A 164 doi:10.1039/j19710000164
Illés J., Burger K., Forrai E., Balogh G. T., Székely Z. (2004): Structure and some physico-chemical properties of zinc hyaluronan. Copyright $\odot$ Matrix Biology Institute. 1-7

Ischiropoulos H., Zhu L., Chen J., Tsai M., Martin J. C., Smith C. D., Beckman J. S. (1992): Peroxynitrite-mediated tyrosine nitration catalyzed by superoxide dismutase. Arch. Biochem. Biophys. 298, 431-437 doi:10.1016/0003-9861(92)90431-U

Ischiropoulos H., Beckman J. S., Crow J. P., Ye Y. Z., Royal J. A., Kooy N. W. (1995): Detection of peroxynitrite. Methods: A Companion to Methods in Enzymology 7, 109-115

Jourd'heuil D., Kang D., Grisham M. B. (1997): Interactions between superoxide and nitric oxide: implications in DNA damage and mutagenesis. Front. Biosci. 2, 189-196

Kamat J. P. (2006): Peroxynitrite: a potent oxidizing and nitrating agent. Indian J. Exp. Biol. 44, 436-447

Kehrer J. P. (2000): The Haber-Weiss reaction and mechanisms of toxicity. Toxicology $149,43-50$ doi:10.1016/S0300-483X(00)00231-6

Kennett E. C., Davies M. J. (2007): Degradation of matrix glycosaminoglycans by peroxynitrite/peroxynitrous acid: evidence for a hydroxyl-radical-like mechanism. Free Radic. Biol. Med. 42, 1278-1289 doi:10.1016/j.freeradbiomed.2007.01.030

Khan A. U., Kovacic D., Kolbanovskiy A., Desai M., Frenkel K., Geacintov N. E. (2000): The decomposition of peroxynitrite to nitroxyl anion $\left(\mathrm{NO}^{-}\right)$and singlet oxygen in aqueous solution. Proc. Natl. Acad. Sci. U.S.A. 97, 2984-2989 doi:10.1073/pnas.050587297

Koppal T., Drake J., Yatin S., Jordan B., Varadarajan S., Bettenhausen L., Butterfield D. A. (1999): Peroxynitrite-induced alterations in synaptosomal membrane proteins: insight into oxidative stress in Alzheimer's disease. J. Neurochem. 72, 310-317 doi:10.1046/j.1471-4159.1999.0720310.x

Koppenol W. H., Moreno J. J., Pryor W. A., Ischiropoulos H., Beckman J. S. (1992): Peroxynitrite, a cloaked oxidant formed by nitric oxide and superoxide. Chem. Res. Toxicol. 5, 834-842 doi:10.1021/tx00030a017

Korkmaz A., Oter S., Seyrek M., Topal T. (2009): Molecular, genetic and epigenetic pathways of peroxynitrite-induced cellular toxicity. Interdisc. Toxicol. 2, 219-228 doi:10.2478/v10102-009-0020-4

Kurz C. R. (2004): Peroxynitrous acid and vitamin C. Dissertation ETH Nr. 15620, Zürich, Switzerland

Leis J. R., Peña M. E., Ríos A. (1993): Novel route to peroxynitrite anion. J. Chem. Soc. Chem. Commun. 16, 1298-1299 doi:10.1039/c39930001298

Li M., Rosenfeld L., Vilar R. E., Cowman M. K. (1997): Degradation of hyaluronan by peroxynitrite. Arch. Biochem. Biophys. 341, 245-250 doi:10.1006/abbi.1997.9970

Linnane A. W., Kios M., Vitetta L. (2007): The essential requirement for superoxide radical and nitric oxide formation for normal physiological function and healthy aging. Mitochondrion 7, $1-5$ doi:10.1016/j.mito.2006.11.009

López-López G., Moreno L., Cogolludo A., Galisteo M., Ibarra M., Duarte J., Lodi F., Tamargo J., Perez-Vizcaino F. (2004): Nitric 
oxide (NO) scavenging and NO protecting effects of quercetin and their biological significance in vascular smooth muscle. Mol. Pharmacol. 65, 851-859

doi:10.1124/mol.65.4.851

Luc R., Vergely C. (2008): Forgotten radicals in biology. Int. J. Biomed. Sci. 4, 255-259

Lyall F., Gibson J. L., Greer I. A., Brockman D. E., Eis A. L., Myatt L. (1998): Increased nitrotyrosine in the diabetic placenta: evidence for oxidative stress. Diabetes Care 21, 1753-1758 doi:10.2337/diacare.21.10.1753

Mangialasche F., Polidori M. C., Monastero R., Ercolani S., Camarda C., Cecchetti R., Mecocci P. (2009): Biomarkers of oxidative and nitrosative damage in Alzheimer's disease and mild cognitive impairment. Ageing Res. Rew. 8, 285-305 doi:10.1016/j.arr.2009.04.002

Martin B. L., Wu D., Jakes S., Graves D. J. (1990): Chemical influences on the specificity of tyrosine phosphorylation. J. Biol. Chem. 265, 7108-7111

Martin-Romero F. J., Gutiérrez-Martin Y., Henao F., GutiérrezMerino C. (2004): Fluorescence measurements of steady state peroxynitrite production upon SIN-1 decomposition: NADH versus dihydrodichlorofluorescein and dihydrorhodamine 123. J. Fluoresc. 14, 17-23 doi:10.1023/B:JOFL.0000014655.89256.bd

Mendoza G., Álvarez A. I., Pulido M. M., Molina A. J., Merino G., Real R., Fernandes P., Prieto J. G. (2007): Inhibitory effects of different antioxidants on hyaluronan depolymerization. Carbohydr. Res. 342, 96-102 doi:10.1016/j.carres.2006.10.027

Murphy M. P., Packer M. A., Scarlett J. L., Martin S. W. (1998): Peroxynitrite: a biologically significant oxidant. Gen. Pharmacol. 31, 179-186 doi:10.1016/S0306-3623(97)00418-7

Myatt L., Rosenfield R. B., Eis A. L., Brockman D. E., Greer I. A., Lyall F. (1996): Nitrotyrosine residues in placenta. Evidence of peroxynitrite formation and action. Hypertension 28, 488-493

Myatt L. (2010): Reactive oxygen and nitrogen species and functional adaptation of the placenta (Review). Placenta 31, Suppl. A, Trophoblast Res. 24, S66-69

Pacher P., Liaudet L., Bai P., Mabley J. G., Kaminski P. M., Virág L., Deb A., Szabó E., Ungvári Z., Wolin M. S., Groves J. T., Szabó C. (2003): Potent metalloporphyrin peroxynitrite decomposition catalyst protects against the development of doxorubicin-induced cardiac dysfunction. Circulation 107, 896-904 doi:10.1161/01.CIR.0000048192.52098.DD

Pacher P., Schulz R., Liaudet L., Szabó C. (2005): Nitrosative stress and pharmacological modulation of heart failure. Trends Pharmacol. Sci. 26, 302-310 doi:10.1016/j.tips.2005.04.003

Pacher P., Szabó C. (2006): Role of peroxynitrite in the pathogenesis of cardiovascular complications of diabetes. Curr. Opin. Pharmacol. 6, 136-141 doi:10.1016/j.coph.2006.01.001

Pacher P., Beckman J. S., Liaudet L. (2007): Nitric oxide and peroxynitrite in health and disease. Physiol. Rev. 87, 315-424 doi:10.1152/physrev.00029.2006

Pérez-De La Cruz V., Gonzáles-Cortés C., Galván-Arzate S., Medina-Campos O. N., Pérez-Severiano F., Ali S. F., Pedraza-
Chaverrí J., Santamaría A. (2005): Excitotoxic brain damage involves early peroxynitrite formation in a model of Huntington's disease in rats: protective role of iron porphyrinate 5,10,15,20-tetrakis (4-sulfonatophenyl)porphyrinate iron (III). Neuroscience 135, 463-474 doi:10.1016/j.neuroscience.2005.06.027

Petriconi G. L., Papee H. M. (1966): Aqueous solutions of sodium pernitrite from alkaline hydrogen peroxide and nitric oxide. Can. J. Chem. 44, 977-980 doi:10.1139/v66-144

Pfeiffer S., Gorren A. C. F., Schmidt K., Werner E. R., Hansert B., Bohle D. S., Mayer B. (1997): Metabolic fate of peroxynitrite in aqueous solution. J. Biol. Chem. 272, 3465-3470

Pietraforte D., Salzano A. M., Marino G., Minetti M. (2003): Peroxynitrite-dependent modifications of tyrosine residues in hemoglobin. Formation of tyrosyl radical(s) and 3-nitrotyrosine. Amino Acids 25, 341-350 doi:10.1007/s00726-003-0021-0

Radi R., Beckman J. S., Bush K. M., Freeman B. A. (1991): Peroxynitrite oxidation of sulfhydryls. The cytotoxic potential of superoxide and nitric oxide. J. Biol. Chem. 266, $4244-4250$

Radi R., Peluffo G., Alvarez M. N., Naviliat M., Cayota A. (2001): Unraveling peroxynitrite formation in biological systems. Free Radic. Biol. Med. 30, 463-488 doi:10.1016/S0891-5849(00)00373-7

Radi R., Cassina A., Hodara R., Quijano C., Castro L. (2002): Peroxynitrite reactions and formation in mitochondria. Free Radic. Biol. Med. 33, 1451-1464 doi:10.1016/S0891-5849(02)01111-5

Radi R. (2004): Nitric oxide, oxidants, and proteine tyrosine nitration. Proc. Natl. Acad. Sci. U.S.A. 101, 4003-4008 doi:10.1073/pnas.0307446101

Rodionov R. N. (2003): Urate as an endogenous antioxidant. Free Radic. Biol. Med. 77, 1-11

Rojas Wahl R. U. (2004): Decomposition mechanism of 3- Nmorpholinosydnonimine (SIN-1) - a density functional study on intrinsic structures and reactivities. J. Mol. Model. 10, 121-129 doi: 10.1007/s00894-004-0178-9

Rork T. H., Hadzimichalis N. M., Kappil M. A., Merrill G. F. (2006): Acetaminophen attenuates peroxynitrite activated matrix metalloproteinase-2-mediated troponin I cleavage in the isolated guinea pig myocardium. J. Mol. Cell. Cardiol. 40, 553-561 doi:10.1016/j.yjmcc.2006.01.010

Saha A., Goldstein S., Cabelli D., Czapski G. (1998): Determination of optimal conditions for synthesis of peroxynitrite by mixing acidified hydrogen peroxide with nitrite. Free Radic. Biol. Med. 24, 653-659 doi:10.1016/S0891-5849(97)00365-1

Salgo M. G., Bermúdez E., Squadrito G. L., Pryor W. A. (1995): Peroxynitrite causes DNA damage and oxidation of thiols in rat thymocytes. Arch. Biochem. Biophys. 322, 500-505 doi:10.1006/abbi.1995.1493

Schönafinger K. (1999): Heterocyclic NO prodrugs. Il Farmaco 54, 316-320 doi:10.1016/S0014-827X(99)00031-2 
Schopfer F. J., Baker P. R., Freeman B. A. (2003): NO-dependent protein nitration: a cell signaling event or an oxidative inflammatory response? Trends Biochem. Sci. 28, 646-654 doi:10.1016/j.tibs.2003.10.006

Schrammel A., Pfeiffer S., Schmidt K., Koesling D., Mayer B. (1998): Activation of soluble guanylyl cyclase by the nitrovasodilator 3-morpholinosydnonimine involves formation of S-nitrosoglutathione. Mol. Pharmacol. 54, 207-212

Sharma V. K., Yngard R. A., Homonnay Z., Dey A., He C. (2010): The kinetics of the interaction between iron(III)-ethylenediaminetetraacetate and peroxynitrite. Aquat. Geochem. 16, 483-490 doi:10.1007/s10498-009-9083-2

Shivashankar K. (2006): Interaction of peroxynitrite with myoglobin and hemoglobin. Can. J. Chem. 84, 788-793 doi: $10.1139 / \mathrm{v} 06-067$

Singh R. J., Hogg N., Joseph J., Konorev E., Kalyanaraman B. (1999): The peroxynitrite generator, SIN-1, becomes a nitric oxide donor in the presence of electron acceptors. Arch. Biochem. Biophys. 361, 331-339 doi:10.1006/abbi.1998.1007

Stankovská M., Hrabárová E., Valachová K., Molnárová M., Gemeiner P., Šoltés L. (2006): The degradative action of peroxynitrite on high-molecular-weight hyaluronan. Neuroendocrinol. Lett. 27 (Suppl 2), 31-34

Stefanovic-Racic M., Stadler J., Evans C. H. (1993): Nitric oxide and arthritis. Arthritis Rheum. 36, 1036-1044 doi:10.1002/art.1780360803

Stern R., Kogan G., Jedrzejas M. J., Šoltés L. (2007): The many ways to cleave hyaluronan. Biotechnol. Adv. 25, 537-557 doi:10.1016/j.biotechadv.2007.07.001

Symons M. C. R. (2000): cis- and trans-Conformations for peroxynitrite anions. J. Inorg. Biochem. 78, 299-301 doi:10.1016/S0162-0134(00)00057-X

Szabó C., Ischiropoulos H., Radi R. (2007): Peroxynitrite: biochemistry, pathophysiology and development of therapeutics. Nature Publishing Group 6, 662-680

Šoltés L., Mendichi R., Kogan G., Schiller J., Stankovská M., Arnhold J. (2006): Degradative action of reactive oxygen species on hyaluronan. Biomacromol. 7, 659-668 doi:10.1021/bm050867v

Torreilles F., Salman-Tabcheh S., Guérin M. C., Torreilles J. (1999): Neurodegenerative disorders: The role of peroxynitrite. Brain Res. Rev. 30, 153-163 doi:10.1016/S0165-0173(99)00014-4
Tsai J. H. M., Harrison J. G., Martin J. C., Hamilton T. P., van der Woerd M., Jablonsky M. J., Beckman J. S. (1994): Role of conformation of peroxynitrite anion (ONOO-) in its stability and toxicity. J. Am. Chem. Soc. 116, 4115-4116 doi:10.1021/ja00088a072

Tsai P. J., Tsai T. H., Yu C. H., Ho S. C. (2007): Comparison of NOscavenging and NO-suppressing activities of different herbal teas with those of green tea. Food Chem. 103, 181-187 doi:10.1016/j.foodchem.2006.08.013

Uppu R. M., Pryor W. A. (1996): Synthesis of peroxynitrite in a twophase system using isoamyl nitrite and hydrogen peroxide. Anal. Biochem. 236, 242-249 doi:10.1006/abio.1996.0162

Valachová K., Rapta P., Kogan G., Hrabárová E., Gemeiner P., Šoltés L. (2009): Degradation of high-molar-mass hyaluronan by ascorbate plus cupric ions: Effects of D-penicillamine addition. Chem. Biodiv. 6, 389-395 doi:10.1002/cbdv.200800261

Vatassery G. T., Smith W. E., Quach H. T. (1998): $\alpha$-Tocopherol in rat brain subcellular fractions is oxidized rapidly during incubations with low concentrations of peroxynitrite J. Nutr. 128, 152-157

Vilar R., Ghael D., Li M., Bhagat D. D., Arrigo L. M., Cowman M. K., Dweck H. S., Rosenfeld L. (1997): Nitric oxide degradation of heparin and heparan sulphate. Biochem. J. 324, 473-479

Ye Y., Quijano C., Robinson K. M., Ricart K. C., Strayer A. L., Sahawneh M. A., Shacka J. J., Kirk M., Barnes S., Accavitti-Loper M. A., Radi R., Beckman J. S., Estévez A. G. (2007): Prevention of peroxynitrite-induced apoptosis of motor neurons and pc12 cells by tyrosine-containing peptides. J. Biol. Chem. 282, 6324-6337 doi:10.1074/jbc.M610800200

Yelamaggad C. V., Mathews M., Hiremath U. S., Shankar Rao D. S., Krishna Prasad S. (2005): Self-assembly of chiral mesoionic heterocycles into smectic phases: a new class of polar liquid crystal. Tetrahedron Lett. 46, 2623-2626 doi:10.1016/j.tetlet.2005.02.084

Zhao W., Diz D. I., Robbins M. E. (2007): Oxidative damage pathways in relation to normal tissue injury. Br. J. Radiol. 80, S23-31 doi:10.1259/bjr/18237646

Received: September 9, 2010

Final version accepted: March 15, 2011 